\title{
Phytotherpy of some Plants Formulas for Albino Rats Suffering from Iron Deficiency Anemia
}

Fatma EL-Zahraa Amin EL-Sherif, ${ }^{1}$ Mohamed Samir EL-Dashlouty, Saad Ahmed Hallabo, and Amal Ali Salama Mohamed ${ }^{1}$

\begin{abstract}
This work was carried out to evaluate some agronomic traits in eleven different genotype. In order to achieve such a purpose 11 different genotypes were kindly obtained from Field Crops Research Institute and cultivated at two different successive seasons and some agronomic traits were evaluated. These agronomic traits are Plant height, Ear height, Days to mid silking, Grain yield/plant, Ear diameter, Kernel depth, No. of rows/ear, No.of kernels/row, Shelling\% and 100-korneal weight. The obtained result showed that differential gene expression was obtained and such result might be used in breeding program and selection.
\end{abstract}

\section{INTRODUCTION}

Iron deficiency (ID) is defined as the decrease of the total content of iron in the body. Iron deficiency anemia (IDA) occurs when ID is sufficiently severe to reduce erythropoiesis. This type of anemia is the most frequent chronic anemia. ID may be the result of either excessive loss or, less frequently, decreased absorption. In general, the iron absorbed daily equals the amount needed to compensate its loss, so that the overall iron pool remains stable. This fine balance is easily broken, because the capability to absorb iron orally is limited, when the inputs are less than necessary or, more frequently, when the outputs increase and cannot be compensated for ID then IDA develops. (Bermejo et al., 2009).

Due to the high prevalence of iron deficiency anemia in developing and industrialized countries, it is necessary to maintain a suitable iron intake through diet in order to achieve an appropriate status of this element in the body. For this reason accurate knowledge of iron availability in foods is essential in order to plan intervention strategies that improve deficient situations of this nutrient (Lopez and Martos, 2004).

Iron refractory (iron deficiency anemia) is a hereditary recessive anemia due to a defect in the TMPRSS6 gene encoding Matriptase-2. This protein is a transmembrane serine protease that plays an essential role in down-regulating hepcidin، the key regulator of iron homeostasis. Hallmarks of this disease are microcytic hypochromic anemia, low transferring saturation and normal/high serum hepcidin values (De Falco et al., 2013)

Phytotherapy is the treatment and prevention of diseases using plants, plant parts, such as leaves, flowers, roots, fruits, and seeds and preparations made from them, these plants called medicinal plants, or herbs (Weiss and Fintelmann, 2000).

According to estimates of the World Health Organization, $80 \%$ of the world population is primarily reliant on traditional methods of healing which use empirical knowledge based on the use of medicinal plants (Muller and Mechler 2005).

Sadighara et al., (2012) reported that plants have a significant role in maintaining human health and improving the quality of human life. The World Health Organization estimated that $80 \%$ of the people depend on traditional medicine.

\section{MATERIALIS AND METHODS}

\section{MATERIALS}

Vegetables: Spinach (Spinacia oleracea), Parsley (Petroselinum crispum), Rocket (Eruca sativa), Celery (Apium graveolens) and Lettuce (Lactuca sativa). The plants were obtained as raw plants from greengroceries. These plants were washed and dried under the sun, then milled and collected as a dried powder

Fruits: Strawberry (Fragaria ananassa), guava (Psidium guajava L.), Ficus (F. carica), apple (Malus domestica) and kiwifruit (Actinidia chinensis). The plants were obtained as raw plants from a fruitier. These plants were washed and dried under the sun, then milled and collected as a dried powder

Herbs: Lemon balm (Melissa officinalis), Marshmallow (Althaea officinalis), Netlle (Urtica dioica L.), Horehound (Marrubium vulgare) and Tilia (T.cordata Mill) were purchased as dry powdered materials from a herbalist.

Seeds: Fenugreek (Trigonella foenicum graecum), Alfalfa (Medicago sativa), kenaf (Hibiscus cannabinus), coriander (Coriandrum sativum L.) and sesamum (Sesamum indicum L.) were purchased as dry powdered materials from a seedsman.

\footnotetext{
${ }^{1}$ Faculty of Home Economics- Minufiya University

${ }^{2}$ Faculty of Agric. Food Science and Technology - Cairo University Received October 22, 2014, Accepted December 7, 2014
} 
Mix of vegetables, fruits, herbs and seeds: Mixture of the above-mentioned plants. These plants were selected to study their effects against anemia iron deficiency.

Chemicals: Tannic acid, casein, vitamins, minerals, cellulose, choline chloride and methionine were obtained from El-Gomhoria Co. for Chemicals and Drugs, Cairo, Egypt.

Animals: A total of 42 normal male albino rats weighing 180-200g were obtained from the Research Institute of Ophthalmology, Cairo, Egypt.

\section{METHODS:}

\section{Study design and blood sampling:}

Male albino rats $(n=42)$ weigh $(180-200 \mathrm{~g})$ were allocated in plastic cages with metallic stainless covers and kept under strict hygienic measures. Rats were fed on basal diet for 7 days for adaptation. Also, water was provided ad libitum via a narrow mouth bottle with a metallic tube tightly fixed at its mouth by a piece of rubber tube. The basal diet used in the experiment was prepared according to Reeves et al., (1993). It consisted of $20 \%$ protein (casein), $10 \%$ sucrose, $4.7 \%$ corn oil, $0.2 \%$ choline chloride, $0.3 \%$ methionine $1 \%$ vitamin mixture, $3.5 \%$ salt mixture and $5 \%$ fiber (cellulose).and corn starch up to $100 \mathrm{~g}$. After this period, rats were divided into two main groups. The first main group (6 rats) was fed on basal diet as a negative control group. The second main group (36 rats) was fed on basal diet containing tannic acid $(20 \mathrm{~g} / \mathrm{kg}$ body weight $)$ for three weeks according to Kaosar et al., (2004). After that 6 rats were kept feeding on basal diet as a positive control group, while the others were randomly divided into 5 groups fed on basal diets containing $7.5 \%$ of either vegetables, fruits, herbs, seeds formulations and mix of vegetables, fruits, herbs and seeds collections. Feeding on plants under study lasted for 28 days. Meanwhile, feed intake recorded daily and body weight recorded once a week.

At the end of the experiment, animals were fasted overnight, then exposed to ether anesthesia and blood samples were withdrawn from eye plexus of veins into heparinized capillary tubes to test blood picture. After sacrificing rats other blood samples were collected from the hepatic portal vein in dry centrifuge tubes. Serum was separated by centrifugation of blood at 3000rpm( round per minute) for 10 minutes at room temperature then transferred into dry clean ebendorf tubes and kept frozen at $-20^{\circ} \mathrm{C}$ till analyzed. Organs (liver-spleenkidney- heart and lungs) were removed by careful dissection, washed in saline solution $(0.9 \%)$, dried using filter paper, and then they were weighed.

\section{Biological Evaluation}

At the end of the experiment, biological evaluation of the tested diet was carried out by determining total feed intake(FI), body weight gain (BWG\%) and feed efficiency ratio (FER) according to Chapman et al., (1959)

\section{Biochemical Analysis}

Complete blood count (CBC) was done using a graded scale (MCV) $(\mathrm{MCH})$ ( $\mathrm{MCHC})$,red blood cell, white blood cells and platelets count were measured according to Fischbach, (1996). Hemoglobin (Hb) concentration was determined according to Drabkin, (1949) while packed cell volume or hematocrit (HCT) was determined according to McInory, (1954).

\section{Determination of serum iron}

Serum samples were analyzed for determination of serum iron according to Wick et al.,(1996).

\section{Determination of total iron binding capacity (TIBC):}

Serum samples were analyzed for determination of total iron binding capacity (TIBC) according to Yamanishi et al.,(2003).

Ferritin assessed according to White et al.,(1986) and transferrin saturation was calculated as (serum iron / TIBC $\times 100$ ).

\section{Statistical Analysis}

The obtained data were statistically analyzed using computerized SPSS (Statistic Program Sigmastat, statistical soft-ware, SAS Institute, Cary, NC). Effects of different treatments were analyzed using one way analysis of variance ANOVA test using Duncan's multiple range test and $\mathrm{p}<0.05$ was used to indicate significance between different groups (Snedecor and Cochran, 1967).

\section{RESULTS AND DISCUSSION}

\section{Biological effects:}

\section{1- Nutritional evaluation:}

Effect of experimental diets on feed intake, body weight gain and feed efficiency ratio is illustrated in Table (1)

It could be observed that anemic rats without treatment $(\mathrm{C}+\mathrm{ve})$ recorded a significant decrease in FI, BWG and FER compared with healthy control (-) group. Anemic groups fed on basal diets containing $7.5 \%$ blends from all plants under study showed apparent increase compared with anemic control group for FI, BWG and FER. Also, it was clear in the same table that no significant difference was found between anemic rats 
Table 1. Effect of feeding with plant formulations diet on FI (Feed intake), BWG \% (bodyweight gain) and FER (Feed efficiency ratio)

\begin{tabular}{|c|c|c|c|c|c|c|c|}
\hline \multirow{2}{*}{ groups } & \multirow[t]{2}{*}{ parameters } & \multicolumn{2}{|c|}{ FI } & \multicolumn{2}{|c|}{ B W G } & \multicolumn{2}{|c|}{ F E R } \\
\hline & & $g / d$ & $\%$ change & $(\%)$ & Change \% & & $\%$ change \\
\hline \multirow{2}{*}{ control } & $\mathrm{C}-$ & $18^{\mathrm{a}} \pm 1.0$ & 40.00 & $28.78^{\mathrm{a}} \pm 0.22$ & 236.6 & $0.071^{\mathrm{a}} \pm 0.009$ & 86.84 \\
\hline & $\mathrm{C}+$ & $12.85^{b} \pm 0.65$ & - & $8.55^{\mathrm{f}} \pm 0.45$ & - & $0.038^{\mathrm{e}} \pm 0.001$ & - \\
\hline \multirow{5}{*}{ 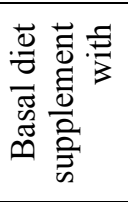 } & Vegetables & $18.10^{\mathrm{a}} \pm 1.1$ & 44.5 & $24.44^{\mathrm{c}} \pm 1.0$ & 185.84 & $0.051^{\mathrm{cd}} \pm 0.002$ & 34.21 \\
\hline & Fruit & $18.5^{\mathrm{a}} \pm 0.5$ & 41.16 & $19.9^{\mathrm{e}} \pm 1.1$ & 132.74 & $0.043^{\mathrm{de}} \pm 0.002$ & 13.61 \\
\hline & Herbs & $18.14^{\mathrm{a}} \pm 0.86$ & 43.9 & $26.12^{\mathrm{b}} \pm 1.38$ & 205.49 & $0.058^{\mathrm{bc}} \pm 0.003$ & 52.63 \\
\hline & Seeds & $18.57^{\mathrm{a}} \pm 0.93$ & 44.5 & $22.8^{\mathrm{d}} \pm 0.7$ & 166.6 & $0.050^{\mathrm{cd}} \pm 0,002$ & 31.5 \\
\hline & Mix & $18.57^{\mathrm{a}} \pm 1.43$ & 40.85 & $28.47^{\mathrm{a}} \pm 1.03$ & 232.98 & $0.061^{b} \pm 0.002$ & 60.52 \\
\hline LSD & & & & 1. & & 0.0 & \\
\hline
\end{tabular}

Values denote arithmetic means \pm standard deviation of the mean. Means with different letters (a, b, c, d) in the same column differ significantly at $\mathrm{p}<0.05$

fed on vegetables groups and anemic rats fed on seeds groups for FER. BEG \&FI of Mix, in comparison with those of the healthy rats. The Mix group revealed the best treatment considering FER.

\section{2- Relative organs weight:}

Effect of experimental diets on relative organs weight of adult rats suffering from iron deficiency anemia was illustrated in Table (2). It could be noticed that there was a significant decrease in organs weight for anemic rats without treatment compared with (Cve) normal rats. The vegetables group showed the best value among all groups for liver and lungs organ while fruits group showed the best value among all groups for heart and kidneys. Also there were no signification changes between anemic rats fed on herbs, seeds and mix groups for all organs weights. Spleen weight was best for vegetable and mix groups with non significant different between them.

\section{Biochemical analysis:}

\section{A- Indices related to iron status in serum:}

Effect of supplementation with the plant under study on iron status in serum of rats suffering from iron deficiency anemia was illustrated in Table (3). It could be observed that the mean values of iron, ferritin and transferritin saturation in serum of untreated anemic groups decreased significantly compared with healthy control group. In contrast, the mean value of serum TIBC increased significantly in untreated anemic groups versus healthy control groups. Anemic rats fed on mix group showed the best result for iron, ferritin and transferritin, while anemic rats fed on fruits group showed the best result for TIBC .Also, it is clear from the results of the same table that there was nonsignificat difference between anemic rats fed on herbs and anemic rats fed on mix for serum iron while for transferritin nonsignificat difference recorded between anemic rats fed on fruits and anemic rats fed on seeds groups

\section{B-CBC tests:}

Effect of supplementation with the studied plant groups on $\mathrm{CBC}$ tests in adult rats suffering from iron deficiency anemia is illustrated in Table (4). It could be noticed that untreated anemic group recorded a significant decrease in $\mathrm{Hb}, \mathrm{HCT}, \mathrm{MCHC}, \mathrm{WBC}$ and $\mathrm{RBC}$ compared with healthy control group in contrast $\mathrm{MCV}, \mathrm{MCH}$, platelat and $\mathrm{RDW}$ which recorded a significant increase compared with healthy control group. It is clear from results of mentioned table that there was nonsignificant difference between anemic rats fed on fruit and anemic rats fed on seeds both MCV and $\mathrm{MCH}$. Also, there was nonsignificant difference between anemic rats fed on vegetables and anemic rats fed on mix group for $\mathrm{Hb}$. also there was nonsignificant difference between anemic rats fed on herbs and anemic rats fed on mix groups for HCT. Regarding MCHC and $\mathrm{RBC}$, it could be noticed there was nonsignificant difference between all studied groups, also it could be noticed that anemic rats fed on mix group showed the best group among all studied groups in all parameters of CBC test.

This result indicated that plants may be beneficial for anemia, this agreed with Ibrahim and Hegazy, (2009) who indicated that rats fed on germinated fenugreek seed flour biscuit diets showed a good hematological response. As well as with EL-Hashash, and Mokhtar, (2012) reported that dietary supplementation with caraway, mint and tilia could be of value in helping patient suffering from iron deficiency anemia. Also, Mahmoud et al., (2012) reported that fenugreek products have good nutritive value and positive response on blood picture and serum biochemical parameters in anemic rats. Therefore, fenugreek products may be beneficial for patients who suffer from iron deficiency anemia due to their nutritional and restorative properties. 


\section{RECOMMENDATIONS}

This study recommends the following:

1- Encouraging the supplementation of food with vegetables, fruits, herbs, seeds as rich foods with iron can help in treatment iron deficiency.

2- Nutritional educational programs should be established to improve awareness to change false nutritional beliefs and to encourage healthy habits. These programs should consider the recent different studies.

\section{REFERENCES}

Bermejo, F.; Santiago and García-López (2009): A guide to diagnosis of iron deficiency and iron deficiency anemia in digestive diseases. J. Gastroenterology 7; 15(37): 46384643

Chapman, D. G.; Castilla, R. and Campbell, J. A. (1959): Evaluation of Protein in Food. I. A method for the deterinination of protein efficiency ration. Can. J. Biochem. Phosiol., 37: 679-686.

Drabkin, D. (1949): The standardization of hemoglobin measurements. Am.J.Med.Sci, 21(7):710

De Falco.; Mayka, S .; Laura, S.; Caroline, K.; Martina, M.; Achille, I.; Laurent, G.; Clara, C. and Carole, B. (2013): Iron refractory iron deficiency anemia. Haematologica.98: 845-853.

EL-Hashash, S. and Mokhtar, E. Y. (2012): Effect of some herbs on iron status in adult rats suffering from iron deficiency anemia. J. Nutr. and Health. (7): 113-128

Fischbach, F.T. (1996): A manual of Laboratory and Diagnostic Tests $5^{\text {th }}$ Ed. P.P. 31-120. Lippincott, Philadephia New York.

Ibrahim, M. and Hegazy, A. (2009): Iron bioavailability of wheat biscuit supplemented by fenugreek seed flour. J. Agri. Sci. 5(6): 769-776.
Kaosar, A.; Kazuki, I. Satoshi and Hiroshi, H.(2004): Effect of ingesting tannic acid on the absorption of iron, but not of zinc, copper and manganese by rats. Biosci. Biotechnol. Biochem., 3:584- 592

Lopez, M. A. A. and Martos, F. C. (2004): Iron availability: An updated review. Internat. J. Food Sci. Nutr., 55(8):597606

Mahmoud, Y. N.; Salem, H. R. and Mater, A.A. (2012): Nutritional and biological assessment of wheat biscuits supplemented by fenugreek plant to improve diet of anemic rats. Acad. J. Nutr., 1(1):01-9

Mc Inory, L. (1954): A micro heamatocrit for determining the packed cell and hemoglobin concentration on capillary blood. J. Clin. Path., (7):32.

Muller, M. S. and Mechler, E. (2005): Medicinal Plants in Tropical Countries. Thieme. Stuttgart. New York.

Reeves, P. G.; Nielson, F. H. and Fahmy, G. C.(1993): Reports of the American Institute of Nutrition, Adhoc Wiling Committee on reformulation of the AIN 93. Rodent Diet. J. Nutri., 123: 1939-1951.

Sadighara, P.; Soraya, G.; Amir, M. J.; Golamreza, J. K. and Samira, S. (2012): The antioxidant and flavonoids contents of Althaea officinalis $L$. flowers based on their color. J. Phytomedicine, 2, (3):113-117.

Snedecor, G. W. and Cochran, W. G. (1967): Statistical Methods. $6^{\text {th }}$ Ed., Iowa State University Press. Ames. Iowa. USA.

Weiss, R. F. and Fintelmann, V. (2000): Herbal Medicine. Second Edition, Thieme. Stuttgart. New York.

Wick, M.; Pinggera W. and Lehmann, P. (1996): Eisenstoffwechsel, Diagnostik und Therapy der Anamien. 3rd Wien/New York: Springer Verlag. and in vitro Protein Digestibility of Roselle Hibiscus sabdariffa L.) Seed. Pak J. Nutr., 7: 50-56.

White, D. Kramer, D. Johnson, G.; Dick, F. and Hamiton, H. (1986):A. M. J. Clin. Path., 72: 346.CF: Enzyme Immunoassay for the Quantitative Determination of Human Ferritin Concentration in Human Serum

Yamanishi, H.; Lyama, S.; Yamaguchi, Y.et al., (2003): Total iron-binding capacity calculated from serum transferrin concentration or serum iron. Clin. Chem., 49: 175-178. 


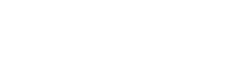

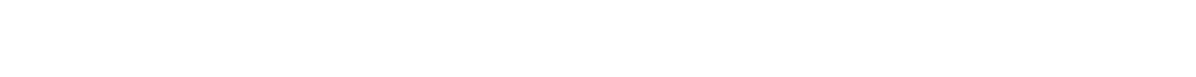

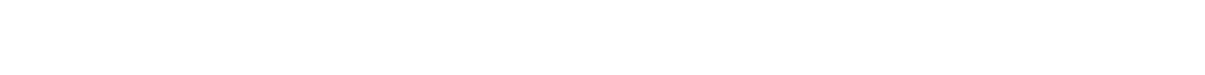

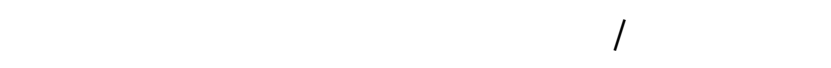

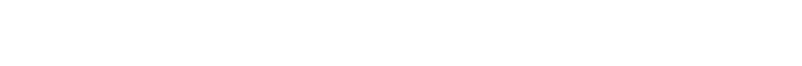

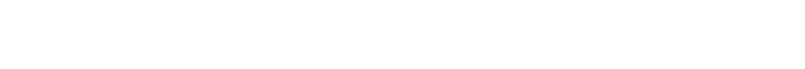

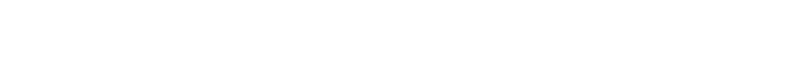

المجموعات الخهس الأخرى بتولفلت النباتلت اللسابق نكرها

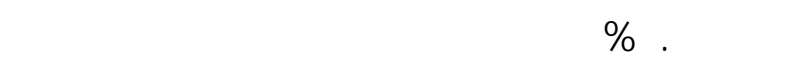

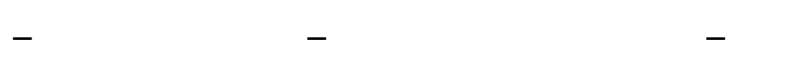

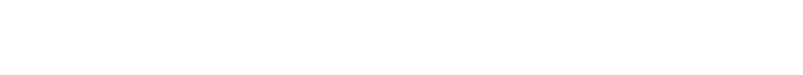
وصورة الهم

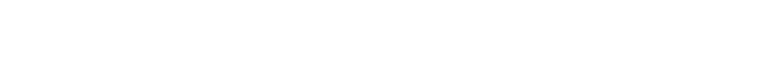

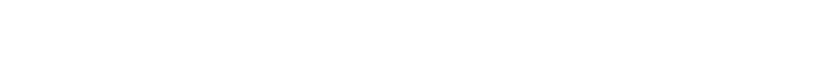

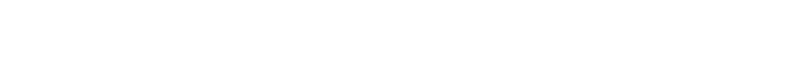
مظم العولمل المدروسة.

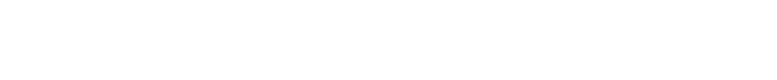
مل الخضروات(سبانخ - جرجير - خس - كرفس - بقدونس)

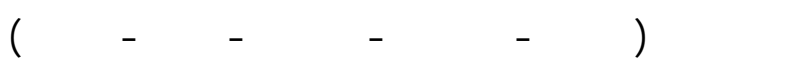

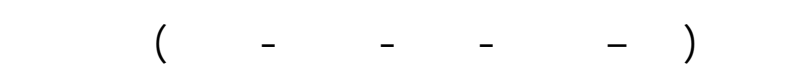

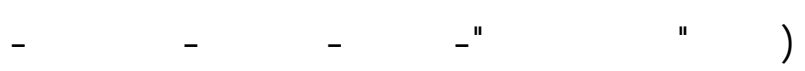

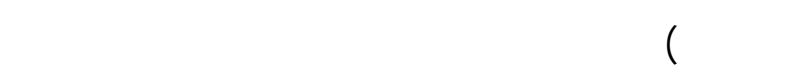
من أنيميا قص الحديد. عل الحن

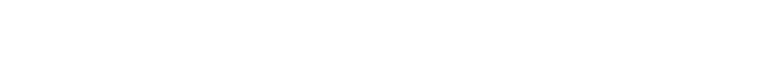

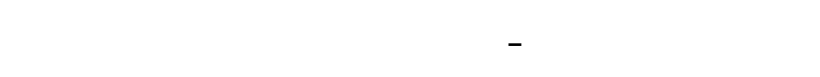

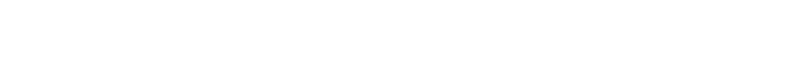

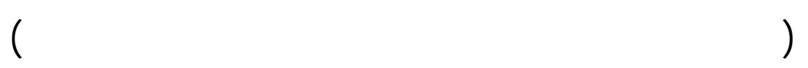

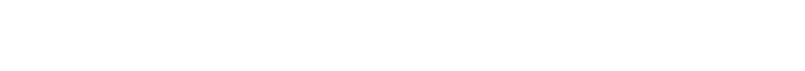

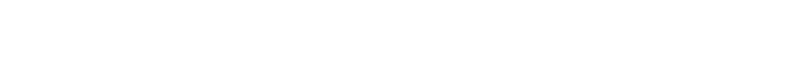

